\title{
Importance of polymorphic variants of Tumour Necrosis Factor - a gene in the etiology of Intrauterine Growth Restriction
}

\author{
Agnieszka Kaluba-Skotarczak' ${ }^{1}$ Justyna Magiełda ${ }^{1}$, Anna Romała ${ }^{1}$, Grażyna Kurzawińska ${ }^{1,2}$, \\ Magdalena Barlik ${ }^{1,2}$, Krzysztof Drews ${ }^{1,2}$, Marcin Ożarowski ${ }^{3,4}$, Tomasz Łoziński' \\ Agnieszka Seremak-Mrozikiewicz ${ }^{1,2}$ \\ ${ }^{1}$ Division of Perinatology and Women's Diseases, Poznan University of Medical Sciences, Poznan, Poland \\ ${ }^{2}$ Laboratory of Molecular Biology, Division of Perinatology and Women's Diseases, \\ Poznan University of Medical Sciences, Poznan, Poland \\ ${ }^{3}$ Department of Pharmacology and Phytochemistry, Institute of Natural Fibers and Medicinal Plants, Poznan, Poland \\ ${ }^{4}$ Department of Pharmaceutical Botany and Plant Biotechnology, Poznan University of Medical Sciences, Poznan, Poland \\ ${ }^{5}$ Department of Obstetrics, Specialist Hospital Pro-Familia in Rzeszow, Rzeszow, Poland
}

\begin{abstract}
Objectives: Intrauterine growth restriction (IUGR) is one of the main global causes of increased perinatal mortality and fetal and neonatal morbidity. It remains a key challenge for modern perinatal medicine. Negative effects of IUGR are manifested not only in the perinatal period but also at the later stages of life. Proinflammatory cytokines and their polymorphisms are hypothesized to play an important role in IUGR pathomechanisms. The aim of the study was to determine the role of selected polymorphisms (-238G $>A,-308 G>A$ and $-376 G>A$ ) of tumor necrosis factor alpha (TNF- $\alpha$ ) in the etiology of intrauterine growth restriction.
\end{abstract}

Material and methods: The study included 120 patients with IUGR (mean age 30.32, mean gestational age 36.34 gestational weeks) and 135 healthy pregnant women (mean age 31.63, average week of delivery 38.76). The investigated polymorphisms were determined by PCR/RFLP methods.

Results: Higher frequency of TNF-a mutated allele $-308 \mathrm{~A}$ was found in a subgroup of women whose pregnancy ended $<37$ weeks ( 18.5 vs. $12.2 \%$ in control , $\mathrm{OR}=1.63, p=0.09$ ) and in the subgroup of women with a score $\geq 3$ UAS ( 20.6 vs. $12.2 \%$ in control $, \mathrm{OR}=1.86, p=0.06$ ). Heterozygous genotype $-308 \mathrm{GA}$ was associated with at least 3 times greater risk of three or four abnormalities in uterine arteries score (41.2 vs. 20.0 in control, $\mathrm{OR}=2.80, p=0.01$ ).

Conclusions: The obtained results suggest that the -308G > A TNF-a gene variant may play a role in the etiology of IUGR in the Polish population, but further studies on larger groups are needed.

Key words: Intrauterine growth restriction (IUGR), tumor necrosis factor alpha (TNF-a), pregnancy, genetic polymorphism

Ginekologia Polska 2018; 89, 3: 159-167

\section{INTRODUCTION}

Intrauterine Growth Restriction (IUGR) despite the constant development and improvment of diagnostic methods still remains one of the most important problems of contemporary perinatal medicine [1-4].

Probably fetal growth disorders are responsible for genetically determined insulin resistance associated with the presence of glucokinase gene mutations and also for the lack of insulin sensitivity in adulthood. This results in abnormal vascular development in the fetal period and may increase the risk of hypertension in the future life. In response to postnatal compensatory hyperinsulinemia, these "small" and "lean" children may preferentially increase the amount of visceral fat tissue, and the cytokines secreted 
by it, i.e. tumor necrosis factor-a (TNF-a) or plasminogen activator inhibitor (PAI-1) which support the state of insulin resistance and increase prothrombotic activity [5].

The proper functioning of the cytokine mesh is a key process for the development of trophoblast and placenta. Functional dysregulation and changes in the local and systemic cytokine system are likely to be involved in many complications during pregnancy. The correct expression of TNF-a has a beneficial role in the development of early pregnancy, affecting the maturation and correct placental differentiation [6]. Currently, it is suggested that TNF-a is crucial for the processes taking place in the placenta, such as the initiation of an inflammatory response, induction of apoptosis, cell proliferation, differentiation and migration. Intrauterine growth restriction with placental insufficiency is most often diagnosed in late pregnancy and sometimes accompanied by significant pathological changes in the placenta. This complication is associated with the reduction of uterine-placental flow. Increased synthesis of TNF-a and other proinflammatory cytokines may be the cause of IUGR in response to increasing hypoxia. TNF-a inhibits the growth of trophoblast and its migration to the walls of the spiral arteries, disrupts the development of the placenta and is toxic to vascular endothelial cells [7]. In addition, TNF-a interferes the anticoagulant system and may cause thrombosis in placental vessels [8]. Therefore, it can directly contribute to the development of IUGR by causing apoptosis of trophoblast cells, insufficient remodelling of spiral arteries, abnormal implantation and placental insufficiency [9].

The gene coding for TNF is located within the genes of mean histocompatibility complex class III (MHC III). In comparison to the other cytokine genes, the gene coding for TNF- $a$ is relatively small ( $3 \mathrm{~kb}$ ) and contains 3 introns and 4 exons, of which the last exon encodes up to $80 \%$ of the final protein product [10]. The TNF gene is specifically located in the 6p21.33 segment on chromosome 6, between the HLA-B and HLA-DR tissue compatibility chip genes. The TNF-a promoter was cloned and sequenced in 1993 by Takashiba et al. It contains many polymorphic sites e.g. at positions: $-1031,-863,-857,-419,-376,-308,-238,-163$ [11].

\section{Aim of the study}

The aim of the study was to evaluate the significance of selected tumour necrosis factor-alpha (TNF-a) gene polymorphisms in the etiology of intrauterine growth restriction (IUGR). This goal was achieved by analyzing the frequency of genotypes and alleles of polymorphisms -238G $>A$, -308G > A and -376G > A of the TNF- $a$ gene, estimation of Doppler flow in uterine arteries and correlation of the studied polymorphisms with Doppler flows.

\section{MATERIAL AND METHODS Study and control group}

The study was conducted in two groups of women: 120 patients who were diagnosed with IUGR during pregnancy (fetal weight $<2$ SD or below the 10th percentile due to a given gestational age and gender) and in the control group of 135 pregnant women who did not have features of intrauterine growth restriction. Patients were qualified to the study and control group within the Department of Perinatology and Women's Diseases at the Medical University of Karol Marcinkowski in Poznań from June 2012 to June 2014.

All patients were informed about the purpose and scope of the study and gave their written consent. The acceptance for performing research was obtained from Bioethics Committee of the Medical University of Karol Marcinkowski in Poznań (No. 145/12).

The mean age of patients in the study group was 30.32 years, the average gestational age at delivery: 36.34 weeks of pregnancy. The study group included: 74 primaparas, and 46 multiparas. During the analysis of the results, the division of 120 women from the study group was carried out twice:

- due to the end of pregnancy

a) subgroup A - 46 women whose pregnancy ended $<37$ weeks

b) subgroup B - 74 women whose pregnancy ended $\geq 37$ weeks

- according to the uterine artery flow rate (UAS) scale

c) subgroup $\mathrm{C}-86$ women with $<3$ UAS points

d) subgroup D -34 women with $\geq 3$ UAS points.

The point scale of uterine artery score (UAS) - point-by-point characterizes the nature of the flow:

- $\quad$ presence of notch in the right uterine artery 1 pt.

- $\quad$ presence of notch in the left uterine artery 1 pt.

- pulsation index PI > 1.2 in the right uterine artery 1 pt.

- pulsation index $\mathrm{PI}>1.2$ in the left uterine artery $1 \mathrm{pt}$.

In the control group, the average age of patients was 31.63 years, and mean pregnancy duration was 38.76 weeks. The control group included: 51 primaparas and 84 multiparas.

All women qualified for in to the study, both IUGR and control groups were Caucasians and of Polish nationality. All women from both groups were in single pregnancy. The gestational age was confirmed based on the date of the last menstrual period, including the regularity and duration of the monthly cycles, ultrasound examination carried out in the first trimester of pregnancy and the date of first fetal movements. In the second trimester of pregnancy, another ultrasound examination was performed in which the presence of fetal malformations was excluded. Clinical characteristics of patients from both groups is presented in Table 1. 
Table 1. Selected clinical data of patients from the IUGR and control group

\begin{tabular}{|c|c|c|c|}
\hline Clinical date of the examined women & $\begin{array}{c}\text { IUGR } \\
(n=120)\end{array}$ & $\begin{array}{l}\text { Control group } \\
(n=135)\end{array}$ & $\mathbf{P}$ \\
\hline $\begin{array}{l}\text { Age (years) } \\
\quad \text { mean } \pm S D \\
\text { min-max } \\
\text { median }\end{array}$ & $\begin{array}{c}30.32 \pm 4.89 \\
17.00-41.00 \\
31.00\end{array}$ & $\begin{array}{c}31.63 \pm 4.68 \\
20.00-45.00 \\
31.00\end{array}$ & 0.03 \\
\hline $\begin{array}{l}\text { Height }[\mathbf{c m}] \\
\text { mean } \pm \text { SD } \\
\text { min-max } \\
\text { median }\end{array}$ & $\begin{array}{c}166.84 \pm 5.90 \\
151.00-184.00 \\
167.00\end{array}$ & $\begin{array}{c}167.53 \pm 5.67 \\
155.00-180.00 \\
168.00\end{array}$ & 0.35 \\
\hline $\begin{array}{l}\text { Weight before pregnancy [kg] } \\
\text { mean } \pm \text { SD } \\
\text { min-max } \\
\text { median }\end{array}$ & $\begin{array}{c}60.68 \pm 9.58 \\
42.00-98.00 \\
60.00\end{array}$ & $\begin{array}{c}65.83 \pm 12.21 \\
45.00-116.00 \\
64.00\end{array}$ & 0.0014 \\
\hline $\begin{array}{l}\text { Weight at pregnancy ending [kg] } \\
\text { mean } \pm \text { SD } \\
\text { min-max } \\
\text { median }\end{array}$ & $\begin{array}{c}72.34 \pm 11.88 \\
47.00-125.00 \\
73.00\end{array}$ & $\begin{array}{c}78.21 \pm 12.01 \\
53.00-121.00 \\
76.00\end{array}$ & 0.0003 \\
\hline $\begin{array}{l}\text { BMI before pregnancy [kg] } \\
\text { mean } \pm \text { SD } \\
\text { min-max } \\
\text { median }\end{array}$ & $\begin{array}{c}21.77 \pm 3.14 \\
15.57-35.14 \\
21.17\end{array}$ & $\begin{array}{c}23.43 \pm 3.96 \\
17.87-36.68 \\
22.60\end{array}$ & 0.0006 \\
\hline $\begin{array}{l}\text { BMI at pregnancy ending }[\mathbf{k g}] \\
\text { mean } \pm \text { SD } \\
\text { min-max } \\
\text { median }\end{array}$ & $\begin{array}{c}25.95 \pm 3.91 \\
17.30-44.82 \\
25.58\end{array}$ & $\begin{array}{c}27.86 \pm 3.95 \\
21.23-40.90 \\
27.51\end{array}$ & 0.0001 \\
\hline $\begin{array}{l}\Delta \text { BMI } \\
\quad \text { mean } \pm \text { SD } \\
\text { min-max } \\
\text { median }\end{array}$ & $\begin{array}{c}4.19 \pm 1.79 \\
0.00-9.68 \\
4.10\end{array}$ & $\begin{array}{c}4.43 \pm 2.09 \\
-1.73-10.29 \\
4.20\end{array}$ & 0.32 \\
\hline $\begin{array}{l}\text { BP syst. [mmHg] } \\
\text { mean } \pm \text { SD } \\
\text { min-max } \\
\text { median }\end{array}$ & $\begin{array}{c}114.83 \pm 11.87 \\
80.00-130.00 \\
120.00\end{array}$ & $\begin{array}{c}112.67 \pm 12.09 \\
80.00-130.00 \\
110.00\end{array}$ & 0.15 \\
\hline $\begin{array}{l}\text { BP diast. [mmHg] } \\
\quad \text { mean } \pm \text { SD } \\
\text { min-max } \\
\text { median }\end{array}$ & $\begin{array}{c}72.38 \pm 9.01 \\
50.00-80.00 \\
80.00\end{array}$ & $\begin{array}{c}70.70 \pm 8.48 \\
50.00-80.00 \\
70.00\end{array}$ & 0.13 \\
\hline $\begin{array}{l}\text { primaparas } \\
\text { multiparas }\end{array}$ & $\begin{array}{l}74(61.67 \%) \\
46(38.33 \%)\end{array}$ & $\begin{array}{l}51(37.78 \%) \\
84(62.22 \%)\end{array}$ & 0.0001 \\
\hline $\begin{array}{l}\text { Delivery } \\
\text { vaginal delivery } \\
\text { cesarian section } \\
\text { operative vaginal delivery } \\
\text { (forceps, vacuum extractor) }\end{array}$ & $\begin{array}{c}33(27.50 \%) \\
84(70.00 \%) \\
3(2.50 \%)\end{array}$ & $\begin{array}{c}55(40.74 \%) \\
78(57.78 \%) \\
2(1.48 \%)\end{array}$ & 0.08 \\
\hline $\begin{array}{l}\text { Cigarette smoking } \\
\text { yes } \\
\text { no }\end{array}$ & $\begin{array}{c}6(5.00 \%) \\
114(95.00 \%)\end{array}$ & $\begin{array}{c}5(3.70 \%) \\
130(96.30 \%)\end{array}$ & 0.61 \\
\hline
\end{tabular}

Each patient was evaluated for the value of Doppler flow in uterine arteries. Patients with multiple pregnancy, prenatally diagnosed congenital malformations, chromosomal aberrations and fetal genetic syndromes, gestational and pregestational diabetes, chronic hypertension, gestational hypertension and pre-eclampsia, threatening premature delivery, chorioamninitis and premature rupture of the membranes were excluded from the study. None of the patient was treated with acetylsalicylic acid and nitric oxide donors.

\section{Ultrasound examination}

In the course of the study, a thorough ultrasound examination was performed in all patients from the IUGR and control group of healthy pregnant women. In order to ensure repeatability of analyzes, all examinations were performed 
by one person and using the same General Electric Voluson 730 Expert (GENERAL ELECTRIC Co, USA).

Ultrasound examinations of fetal biometry and Doppler flows in the right and left uterine arteries (RUA, LUA) were performed. The parameters used in the ultrasound devise were constant. The angle of incidence of ultrasound was adjusted to the vessel in which the Doppler flow was assessed and did not exceed $30^{\circ}$. During the Doppler examination, a dose of energy not exceeding $50 \mathrm{~mW} / \mathrm{cm}^{2}$ (lower than the limit values adopted by the American Institute of Medical Ultrasonography) was used. Each test was conducted in a semi-recumbent position on the left side to avoid the so-called lower vena cava syndrome caused by the pressure of the pregnant uterus. The exposure time for ultrasound did not exceed 15 minutes.

\section{Genetic analysis}

The genetic analysis examined the incidence of three promoter polymorphisms of the TNF-a gene: -238G > A, $-308 G>A,-376 G>A$. The analysis of genetic polymorphisms was performed by polymerase chain reaction (PCR) and restriction fragment length polymorphism (RFLP). Genetic analysis was carried out at the Laboratory of Molecular Biology at the Department of Perinatology and Women's Diseases of the Medical University of Poznan.

Leukocyte DNA isolation was performed using a commercial QIAamp DNA Blood Kit (QIAGEN Inc., Germany).

The isolated DNA was stored at minus $80^{\circ} \mathrm{C}$. After isolation, the obtained DNA was checked by spectrophotometric measurement (BioPhotometer, Eppendorf, USA) and electrophoresis on $0.8 \%$ agarose gels, where the DNA was visible as a single band.

For amplification of the TNF- $a$ gene fragment containing the $-376 G>A$ polymorphism, primers with the following sequences were used: 5'-AAg AAT CATTCA ACC AgC gg-3' and 5'-CCT CAA Cgg ACT CAg CCTTC-3' (TibMolBiol, Poland). The length of the $P C R$ product was $393 \mathrm{bp}$. For the amplification of the segment containing $-238 \mathrm{G}>A$ and $-308 \mathrm{G}>A$ polymorphisms, the following primers were used: $5^{\prime}$-AAA Tgg Agg CAA Tag gTT TTg Agg ggC TTg-3' and 5'-TAC CCC TCA CACTCC CCA TCCTCC CTg ATC-3' (TIBMolBiol Poland), which allowed to obtain a fragment of $131 \mathrm{bp}$. (underlined letter A means mismatch at the 3 'end of the primer to the sequence to introduce the restriction site for the BspPI restriction enzyme). All reactions were performed using the Dyad DNA Engine thermal cycler (BioRad, USA).

The PCR products were hydrolyzed with restriction enzymes:Tasl (Tsp509l) for -376G > A, BspPI (Alwl) for -238G > A and Faql (BsmFI) for $-308 G>A$. All reactions were carried out according to the procedures recommended by the manufacturer. Genotype identification was performed by means of electrophoresis on 3\% agarose gels in TBE buffer. The gels were stained with Midori Green DNA Stain (NIPPON Genetics, Germany) and visualized under UV light. Depending on the genotype, the following fragments were obtained: -376G > A (GG - 393, GA - 393, 319, 74, $A A-319,74 \mathrm{bp})$, $-238 \mathrm{G}>\mathrm{A}(\mathrm{GG}-110,21, \mathrm{GA}-131,110,21, A A-131 \mathrm{bp})$, $-308 G>A(G G-86,45, G A-131,86,45, A A 131$ bp).

\section{Statistical analysis}

The statistical analysis of the obtained results was performed using the SPSS 22.0 PL statistical program for Windows. The distribution of continuous variables in terms of its compatibility with the normal distribution was assessed using the Kolmogorov-Smirnov test with the Lilliefors amendment.

The results of genetic tests were statistically analyzed, the frequency of occurrence of genotypes and alleles between the test group and the control group was compared. A chi square test and one-sided Fisher exact test were used. The risk ratio (WR) was also calculated regarding the appropriate confidence intervals $(95 \% \mathrm{Cl})$. The $p$ value $<0.05$ was considered statistically significant. The observed values of the occurrence frequency of particular genotypes were compared with the expected values, which were determined based on the frequency of alleles according to the Hardy-Weinberg law.

The analysis of linkage disequilibrium for the studied polymorphisms of the TNF-a gene and the analysis of the incidence of haplotypes was carried out using the Haploview version 4.2 program. The significance correction for multiple testing (1000 permutations) included in the program was also used.

\section{RESULTS}

\section{Analysis of the presence of TNF-a gene polymorphisms}

-238G > A TNF-a gene polymorphism

As a result of TNF- $a-238 G>A$ polymorphism analysis, more frequent occurrences of -238GG non mutated homozygotes were observed in the control group ( 91.9 vs. 88.3\% in the group with hypotrophy, $\mathrm{OR}=0.67, p=0.23$ ) and genotype $-238 \mathrm{GA}$ was more frequent in the study group (11.7 vs. $8.1 \%, \mathrm{OR}=1.49, p=0.23$ ). The study did not report the presence of a homozygous mutated -238AA genotype among the studied women.

The incidence of alleles did not differ significantly between the groups: for the mutated $-238 \mathrm{~A}$ allele (5.8 vs. $4.1 \%$, $\mathrm{WR}=1.46, p=0.23)$, and for the wild-type allele $-238 \mathrm{G}$ (94.2 vs. 95.9\%, WR $=0.69, p=0.23$ ). The distribution of genotypes and alleles in both groups met the assumptions of the Hardy-Weinberg equilibrium (test group: chi square $=0.46$, $p=0.50$ and control group: chi square $=0.24, p=0.62$ ). The obtained results are presented in Table 2 . 
Table 2. Incidence of genotypes and alleles of TNF- $a$ gene polymorphisms in the group of women with IUGR and in the control group

\begin{tabular}{|c|c|c|c|c|c|c|c|c|}
\hline & \multirow{2}{*}{ TNF- $a$} & \multicolumn{2}{|c|}{$\begin{array}{c}\text { IUGR } \\
(n=120)\end{array}$} & \multicolumn{2}{|c|}{$\begin{array}{l}\text { Control group } \\
(n=135)\end{array}$} & \multirow{2}{*}{ OR } & \multirow{2}{*}{ 95\%PU } & \multirow{2}{*}{$\mathbf{p}$} \\
\hline & & $\begin{array}{l}\text { Observed value } \\
\text { n (\%) }\end{array}$ & $\begin{array}{l}\text { Expected value } \\
(\%)\end{array}$ & $\begin{array}{c}\text { Observed value } \\
\text { n (\%) }\end{array}$ & $\begin{array}{c}\text { Expected value } \\
(\%)\end{array}$ & & & \\
\hline \multirow{8}{*}{$\begin{array}{l}\nwarrow \\
\hat{N} \\
\stackrel{0}{0} \\
\stackrel{m}{1}\end{array}$} & GG & $117(97.5)$ & 97.5 & $134(99.3)$ & 99.3 & 0.29 & $0.03-2.84$ & 0.27 \\
\hline & GA & $3(2.5)$ & 2.5 & $1(0.7)$ & 0.7 & 3.44 & $0.35-33.48$ & 0.27 \\
\hline & AA & $0(0.0)$ & 0.0 & $0(0.0)$ & 0.0 & - & - & - \\
\hline & Total & $120(100.0)$ & & $135(100.0)$ & & & & \\
\hline & Alleles & & & & & & & \\
\hline & G & $237(98.7)$ & - & $269(99.6)$ & - & 0.29 & $0.03-2.84$ & 0.27 \\
\hline & A & $3(1.3)$ & - & $1(0.4)$ & - & 3.41 & $0.35-32.96$ & 0.27 \\
\hline & Total & $240(100.0)$ & & $270(100.0)$ & & & & \\
\hline \multirow{8}{*}{$\begin{array}{l}\varangle \\
\hat{y} \\
\stackrel{O}{0} \\
\stackrel{P}{1}\end{array}$} & GG & $83(69.2)$ & 70.2 & 105 (77.8) & 77.0 & 0.64 & $0.37-1.12$ & 0.08 \\
\hline & GA & $35(29.2)$ & 27.2 & $27(20.0)$ & 21.5 & 1.65 & $0.93-2.93$ & 0.06 \\
\hline & $\mathrm{AA}$ & $2(1.6)$ & 2.6 & $3(2.2)$ & 1.5 & 0.75 & $0.12-4.54$ & 0.56 \\
\hline & Total & $120(100.0)$ & & $135(100.0)$ & & & & \\
\hline & Alleles & & & & & & & \\
\hline & G & $201(83.7)$ & - & $237(87.8)$ & - & 0.72 & $0.44-1.18$ & 0.12 \\
\hline & A & 39 (16.3) & - & $33(12.2)$ & - & 1.39 & $0.84-2.30$ & 0.12 \\
\hline & Total & $240(100.0)$ & & $270(100.0)$ & & & & \\
\hline \multirow{8}{*}{$\begin{array}{l}\ll \\
\hat{্} \\
\stackrel{\sim}{\sim}\end{array}$} & GG & $106(88.3)$ & 88.7 & $124(91.9)$ & 92.0 & 0.67 & $0.29-1.54$ & 0.23 \\
\hline & GA & 14 (11.7) & 11.0 & $11(8.1)$ & 7.8 & 1.49 & $0.65-3.42$ & 0.23 \\
\hline & AA & $0(0.00)$ & 0.3 & $0(0.00)$ & 0.2 & - & - & - \\
\hline & Total & $120(100.0)$ & & $135(100.0)$ & & & & \\
\hline & Alleles & & & & & & & \\
\hline & G & $226(94.2)$ & - & $259(95.9)$ & - & 0.69 & $0.31-1.54$ & 0.23 \\
\hline & A & $14(5.8)$ & - & $11(4.1)$ & - & 1.46 & $0.65-3.28$ & 0.23 \\
\hline & Total & $240(100.0)$ & & $270(100.0)$ & & & & \\
\hline
\end{tabular}

\section{-308G > A TNF-a gene polymorphism}

During the analysis of the frequency of genotypes and alleles of the $-308 \mathrm{G}>A$ polymorphism, a higher turnout of homozygous genotype -308GG and homozygous mutated $-308 A A$ genotype in the control group of healthy women was recorded compared to the study group $(77.8 \%$ vs. $69.2 \%$ and $2.2 \%$ vs. $1.6 \%$ in the group with hypotrophy, $p=0.08$ and $p=0.56$ ). The opposite situation was observed in the case of the heterozygous $-308 \mathrm{GA}$ genotype, which was more frequent in the group of women with IUGR (29.2\% vs. $20.0 \%$ in the control group, $p=0.06$ ).

When analyzing the incidence of alleles for this polymorphism, it was observed that the mutated allele $-308 \mathrm{~A}$ was more frequent in the study group $(16.3 \%$ vs. $12.2 \%$, $\mathrm{OR}=1.39, p=0.12$ ), while in the control group the wild allele $-308 \mathrm{G}$ was more frequent $(87.8 \% \mathrm{vs} .83 .7 \%$ in the group with hypotrophy, $\mathrm{OR}=0.72, p=0.12$ ) (Tab. 3). Both studied groups met the Hardy-Weinberg equilibrium assumptions (test group: chi square $=0.61, p=0.43$ and control group: chi square $=0.62, p=0.43)($ Tab. 2$)$.

\section{-376G > A TNF-a gene polymorphism}

For TNF- $a$ gene $-376 G>A$ polymorphism, none of the patients had a genotype containing both mutated -376AA alleles. In the group of women with fetal hypotrophy, the heterozygous genotype $-376 \mathrm{GA}$ was more frequent (2.5 vs. $0.7 \%$ in the control group, $\mathrm{OR}=3.44, p=0.27$ ).

During the analysis, a higher incidence of the mutated $-386 \mathrm{~A}$ allele was also observed, which was $1.3 \%$ compared to the control group of $0.4 \%(\mathrm{OR}=3.41, p=0.27)$. The analyzed groups of women met the assumptions of the Hardy-Weinberg balance (test group: chi square $=0.01, p=0.89$ and control group: chi square $=0.002, p=0.97$ ). The obtained results are presented in Table 2 . 


\section{Analysis of the prevalence of genotypes and alleles of TNF-a polymorphisms depending on the week of pregnancy ending}

Analysis of the frequency of occurrence of genotypes and alleles of the studied polymorphisms was performed after dividing the study group of women into two subgroups due to pregnancy ending (subgroup A - ending of pregnancy $<37$ weeks, subgroup $B$ - ending of pregnancy $\geq 37$ weeks).

For the polymorphism -376G $>A$, there were no genotypes containing the mutated $-376 \mathrm{~A}$ allele in the $A$ subgroup of women giving birth before 37 weeks, while in the subgroup of giving birth after 37 weeks three patients were carriers of the heterozygous $-376 \mathrm{GA}$ genotype ( $4.1 \% \mathrm{vs} .0 .7 \%$ in the control group, $\mathrm{OR}=5.66, p=0.13$ ). The mutated $-376 \mathrm{~A}$ allele occurred in $2.0 \%$ of women giving birth after 37 weeks and in $0.4 \%$ in the control group, this difference was not statistically significant $(p=0.13)$.
For polymorphism-308G $>A$, the most interesting observation was higher frequency of heterozygous genotype -308GA in the group where the birth took place $<37$ weeks $(32.6 \%$ vs. $20.0 \%, \mathrm{OR}=1.94, p=0.06$ ). There was also a higher incidence of the $-308 \mathrm{~A}$ mutated allele in this subgroup (18.5 vs. $12.2 \%$ ). Similar results were obtained by examining the distribution of alleles and genotypes for this polymorphism in the B subgroup of women giving birth after 37 weeks. The 306GA heterozygous genotype was observed more frequently compared to the control group (27.0 vs. $20.0 \%$ ). The genotype containing both mutated $-308 \mathrm{AA}$ alleles occurred more frequently in the control group ( 2.2 vs. $1.4 \%$ in the subgroup $>37$ weeks). The incidence of the $-308 \mathrm{~A}$ mutated allele was higher in the subgroup $>37$ weeks ( 14.9 vs. $12.2 \%, \mathrm{OR}=1.25, p=0.27$ ).

For polymorphism -238G >A of the TNF- $a$ gene in the group of women who delivered children with hypotrophy $<37$ weeks a lower incidence of -238GG genotype was ob-

Table 3. Incidence of genotypes and alleles of TNF-a gene polymorphisms in the subgroups separated due to the end of pregnancy and in the control group

\begin{tabular}{|c|c|c|c|c|c|c|c|c|c|c|c|}
\hline \multirow{2}{*}{\multicolumn{2}{|c|}{ TNF- $a$}} & \multicolumn{4}{|c|}{ Childbirth $<37$ tc. $(n=46)$} & \multicolumn{4}{|c|}{ Childbirth $\geq 37$ tc. $(n=74)$} & \multicolumn{2}{|c|}{$\begin{array}{l}\text { Control group } \\
(n=135)\end{array}$} \\
\hline & & $\begin{array}{c}\text { Observed } \\
\text { value } n(\%)\end{array}$ & $\begin{array}{l}\text { Expected } \\
\text { value (\%) }\end{array}$ & OR & $\mathbf{p}$ & $\begin{array}{l}\text { Observed } \\
\text { value } n(\%)\end{array}$ & $\begin{array}{l}\text { Expected } \\
\text { value (\%) }\end{array}$ & OR & $\mathbf{p}$ & $\begin{array}{c}\text { Observed } \\
\text { value } \mathrm{n}(\%)\end{array}$ & $\begin{array}{l}\text { Expected } \\
\text { value (\%) }\end{array}$ \\
\hline \multirow{8}{*}{$\begin{array}{l}\varangle \\
\hat{N} \\
\stackrel{0}{0} \\
\hat{r}\end{array}$} & GG & $46(100.0)$ & 100.0 & - & - & $71(95.9)$ & 96.0 & 0.18 & 0.13 & $134(99.3)$ & 99.3 \\
\hline & GA & $0(0.0)$ & 0.0 & - & - & $3(4.1)$ & 4.0 & 5.66 & 0.13 & $1(0.7)$ & 0.7 \\
\hline & $\mathrm{AA}$ & $0(0.0)$ & 0.0 & - & - & $0(0.0)$ & 0.0 & - & - & $0(0.0)$ & 0.0 \\
\hline & Total & $46(100.0)$ & & & & $74(100.0)$ & & & & $135(100.0)$ & \\
\hline & Alleles & & & & & & & & & & \\
\hline & G & $92(100.0)$ & - & - & - & $145(98.0)$ & - & 0.18 & 0.13 & 269 (99.6) & - \\
\hline & A & $0(0.0)$ & - & - & - & $3(2.0)$ & - & 5.57 & 0.13 & $1(0.4)$ & - \\
\hline & Total & $92(100.0)$ & & & & $148(100.0)$ & & & & $270(100.0)$ & \\
\hline \multirow{8}{*}{$\begin{array}{l}\varangle \\
\hat{y} \\
\stackrel{0}{0}\end{array}$} & GG & $30(65.2)$ & 66.5 & 0.54 & 0.07 & $53(71.6)$ & 72.5 & 0.72 & 0.20 & $105(77.8)$ & 77.0 \\
\hline & GA & $15(32.6)$ & 30.1 & 1.94 & 0.06 & $20(27.0)$ & 25.3 & 1.48 & 0.16 & $27(20.0)$ & 21.5 \\
\hline & $\mathrm{AA}$ & $1(2.2)$ & 3.4 & 0.98 & 0.73 & $1(1.4)$ & 2.2 & 0.60 & 0.55 & $3(2.2)$ & 1.5 \\
\hline & Total & $46(100.0)$ & 100.0 & & & $74(100.0)$ & 100.0 & & & $135(100.0)$ & \\
\hline & Alleles & & & & & & & & & & \\
\hline & G & $75(81.5)$ & - & 0.61 & 0.09 & $126(85.1)$ & - & 0.80 & 0.27 & 237 (87.8) & - \\
\hline & A & $17(18.5)$ & - & 1.63 & 0.09 & $22(14.9)$ & - & 1.25 & 0.27 & $33(12.2)$ & - \\
\hline & Total & $92(100.0)$ & - & & & $148(100.0)$ & - & & & $270(100.0)$ & \\
\hline \multirow{8}{*}{ 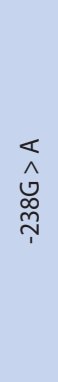 } & GG & $41(89.1)$ & 89.4 & 0.73 & 0.38 & $65(87.8)$ & 88.2 & 0.64 & 0.24 & 124 (91.9) & 92.0 \\
\hline & GA & $5(10.9)$ & 10.3 & 1.37 & 0.38 & $9(12.2)$ & 11.4 & 1.56 & 0.24 & $11(8.1)$ & 7.8 \\
\hline & AA & $0(0.0)$ & 0.3 & - & - & $0(0.0)$ & 0.4 & - & - & $0(0.00)$ & 0.2 \\
\hline & Total & $46(100.0)$ & 100.0 & & & $74(100.0)$ & 100.0 & & & $135(100.0)$ & \\
\hline & Alleles & & & & & & & & & & \\
\hline & G & $87(94.6)$ & - & 0.74 & 0.38 & 139 (93.9) & - & 0.66 & 0.24 & 259 (95.9) & - \\
\hline & A & $5(5.4)$ & - & 1.35 & 0.38 & $9(6.1)$ & - & 1.52 & 0.25 & $11(4.1)$ & - \\
\hline & Total & $92(100.0)$ & - & & & $148(100.0)$ & - & & & $270(100.0)$ & \\
\hline
\end{tabular}


served (89.1 vs. $91.9 \%$ in the control group, $\mathrm{OR}=0.73, p=0.38$ ) and a higher incidence of the heterozygous -238GA genotype containing one mutated allele (10.9 vs. $8.1 \%$ in the control group, $\mathrm{OR}=1.37, p=0.38$ ). Similar observations were made for the frequency of alleles of this polymorphism. The -238G allele was less frequent in the subgroup < 37 weeks ( 94.6 vs. $95.9 \%$, $\mathrm{OR}=0.74$ ), while the $-238 \mathrm{~A}$ mutated allele appeared more frequently in the examined subgroup ( $5.4 \mathrm{vs.} 4.1 \%, \mathrm{OR}=1.35$, $p=0.38$ ). In the subgroup giving birth after 37 weeks the mutated $-238 \mathrm{~A}$ allele was even more frequent $(6.1 \mathrm{vs} .4 .1 \%$ in the OR control group $=1.52, p=0.25$ ), and the wild type $-238 \mathrm{G}$ allele occurred in this subgroup in $93.9 \%$ of women (Tab. 3 ).

\section{Analysis of the prevalence of genotypes and alleles of TNF-a polymorphisms depending on the UAS score}

In the next stage of the research, the study group was divided into two subgroups taking into account the point scale of uterine artery flow (UAS) (subgroup C -86 women with $<3$ points, subgroup $D-34$ women with $\geq 3$ points)

In terms of TNF-a gene polymorphism, -376GA heterozygous genotype was more frequent in patients who scored less than three points in the UAS scale $(3.5 \%$ vs. $0.7 \%$ in the control group, $\mathrm{OR}=0.21 p=0.16$ ). In a subgroup of 34 women who scored three or more points, only a homozygous unmuted genome was found $-376 G G$.

Interesting results were obtained during the analysis of the -308G > A polymorphism of the TNF-a gene. Among women from subgroup $D$ : with three or more points of the UAS scale, the heterozygous genotype -308GA occurred more than twice as often as in the control group $(41.2 \%$ vs. $20.0 \%$, $\mathrm{OR}=2.80, p=0.01)$. In this subgroup, there was no single patient with a genotype containing both mutated alleles. Genotype -308AA occurred in subgroup C in two patients (2.3\%) and in the control group in three (2.2\%). When analyzing the distribution of alleles in these subgroups and in the control

\begin{tabular}{|c|c|c|c|c|c|c|c|c|c|c|c|}
\hline \multirow{2}{*}{\multicolumn{2}{|c|}{ TNF- $a$}} & \multicolumn{4}{|c|}{$<3$ points UAS $(n=86)$} & \multicolumn{4}{|c|}{$\geq 3$ points UAS $(n=34)$} & \multicolumn{2}{|c|}{$\begin{array}{l}\text { Control group } \\
(n=135)\end{array}$} \\
\hline & & $\begin{array}{l}\text { Observed } \\
\text { value } n(\%)\end{array}$ & $\begin{array}{l}\text { Expected } \\
\text { value }(\%)\end{array}$ & OR & p & $\begin{array}{l}\text { Observed } \\
\text { value } n(\%)\end{array}$ & $\begin{array}{l}\text { Expected } \\
\text { value (\%) }\end{array}$ & OR & p & $\begin{array}{l}\text { Observed } \\
\text { value } n(\%)\end{array}$ & $\begin{array}{l}\text { Expected } \\
\text { value (\%) }\end{array}$ \\
\hline \multirow{8}{*}{$\begin{array}{l}\ll \\
\hat{0} \\
\hat{m}\end{array}$} & GG & $83(96.5)$ & 96.54 & 0.21 & 0.16 & $34(100.0)$ & 100.0 & - & - & $134(99.3)$ & 99.3 \\
\hline & GA & $3(3.5)$ & 3.43 & 4.84 & 0.16 & $0(0.0)$ & 0.0 & - & - & $1(0.7)$ & 0.7 \\
\hline & $A A$ & $0(0.0)$ & 0.03 & - & - & $0(0.0)$ & 0.0 & - & - & $0(0.0)$ & 0.0 \\
\hline & Total & $86(100.0)$ & 100.0 & & & $34(100.0)$ & & & & $135(100.0)$ & \\
\hline & Alleles & & & & & & & & & & \\
\hline & G & $169(98.3)$ & - & 0.21 & 0.17 & $68(100.0)$ & - & - & - & $269(99.6)$ & \\
\hline & A & $3(1.7)$ & - & 4.78 & 0.17 & $0(0.0)$ & - & - & - & $1(0.4)$ & \\
\hline & Total & $172(100.0)$ & - & & & $68(100.0)$ & - & & & $270(100.0)$ & \\
\hline \multirow{8}{*}{$\begin{array}{l}\varangle \\
\hat{y} \\
0 \\
\text { O }\end{array}$} & GG & $63(73.3)$ & 62.8 & 0.78 & 0.27 & $20(58.8)$ & 63.1 & 0.41 & 0.02 & 105 (77.8) & 77.0 \\
\hline & GA & $21(24.4)$ & 21.4 & 1.29 & 0.27 & $14(41.2)$ & 32.7 & 2.80 & 0.01 & $27(20.0)$ & 21.5 \\
\hline & AA & $2(2.3)$ & 1.8 & 1.05 & 0.64 & $0(0.0)$ & 4.2 & - & - & $3(2.2)$ & 1.5 \\
\hline & Total & $86(100.0)$ & & & & $34(100.0)$ & & & & $135(100.0)$ & \\
\hline & Alleles & & & & & & & & & & \\
\hline & G & $147(85.5)$ & - & 0.81 & 0.29 & $54(79.4)$ & - & 0.54 & 0.06 & $237(87.8)$ & - \\
\hline & A & $25(14.5)$ & - & 1.22 & 0.29 & $14(20.6)$ & - & 1.86 & 0.06 & $33(12.2)$ & - \\
\hline & Total & $172(100.0)$ & - & & & $68(100.0)$ & - & & & $270(100.0)$ & \\
\hline \multirow{8}{*}{ 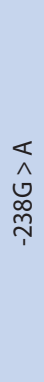 } & GG & $75(87.2)$ & 87.6 & 0.60 & 0.18 & $31(91.2)$ & 91.4 & 0.92 & 0.56 & 124 (91.9) & 92.0 \\
\hline & GA & $11(12.8)$ & 12.0 & 1.65 & 0.18 & $3(8.8)$ & 8.4 & 1.09 & 0.56 & $11(8.1)$ & 7.8 \\
\hline & AA & $0(0.0)$ & 0.4 & - & - & $0(0.0)$ & 0.2 & - & - & $0(0.00)$ & 0.2 \\
\hline & Total & $86(100.0)$ & & & & $34(100.0)$ & & & & $135(100.0)$ & \\
\hline & Alleles & & & & & & & & & & \\
\hline & G & 161 (93.6) & & 0.62 & 0.19 & $65(95.6)$ & & 0.92 & 0.56 & $259(95.9)$ & - \\
\hline & A & $11(6.4)$ & & 1.61 & 0.19 & $3(4.4)$ & & 1.09 & 0.56 & $11(4.1)$ & - \\
\hline & Total & $172(100.0)$ & & & & $68(100.0)$ & & & & $270(100.0)$ & \\
\hline
\end{tabular}


group, the occurrence of the $-308 \mathrm{G}$ allele was the most frequent in the control group - $87.8 \%$, in $85.5 \%$ of women who obtained more than three points in the UAS scale and in $79.4 \%$ of patients with three and more points. The $-308 \mathrm{~A}$ mutated allele was most frequently observed in subgroup $\mathrm{D}(20.6 \%$ vs. $12.2 \%$ in the control group, $\mathrm{OR}=0.54, p=0.06)$.

In the case of TNF- $a-238 G>A$ polymorphism analysis, the most frequent occurrence of the genotype containing the $-238 \mathrm{~A}$ mutant allele was in the subgroup of women who scored less than three points $(12.8 \%$ vs. $8.1 \%$ in the control group, $\mathrm{OR}=0.60, p=0.18$ ). The incidence of genotypes and alleles of this variant in the subgroup of women with less than three UAS points was comparable to the frequency of the control group: -238GG - 91.2 vs. $91.9 \%$, $-238 G A-8.8$ vs. $8.1, G$ allele 95.6 vs. $95.9 \%$ and the $-238 A$ allele 4.4 vs. $4.1 \%$ (Tab. 4).

\section{DISCUSSION}

The number of reports in the world literature analyzing the incidence of cytokine polymorphisms in pregnant women diagnosed with IUGR is low. Hence, the studies carried out in the above work in the group of women with IUGR without any other accompanying complications are very interesting, both in terms of the collected group and the obtained results. In the analyzed group of women, no direct significance of any of the studied polymorphisms $(-238 G>A,-308 G>A,-376 G>A)$ of the TNF- $a$ gene in the etiology of IUGR was indicated. The results indicate that the $-308 \mathrm{G}>A$ polymorphism of TNF- $a$ gene was more frequent in the subgroup of women who had a birth $<37 \mathrm{gw}$. $(\mathrm{p}=0.06)$ and in the subgroup of women with $\geq 3$ points. UAS (scale of flow through the uterine arteries) $(p=0.01$ ) (for the allele-308A $p=0.06$ ). In the other papers, the Authors also indicate the importance of the -308G > A TNF- $a$ variant in the development of hypotrophy [12-15].

An attempt to explain the contribution of placental cytokine gene polymorphisms in the mechanism of IUGR formation was made by researchers from Sweden. They analyzed gene expression and selected polymorphisms in 44 newborns with IUGR and 55 with normal body mass from the Pakistani population, where IUGR is more common than in Sweden. There were no statistically significant differences in mRNA expression for the TNF-a gene and the incidence of $-308 G>A$ polymorphism between the neonatal groups and their mothers. When comparing the incidence of this polymorphism in Pakistani women with Swedish Caucasians, a statistically significant difference was found $(p<0.04)$ [13].

In addition, in the present study, genetic coexistence was analyzed to assess the significance of genetic variants of TNF-a gene polymorphisms. An interesting observation of a higher frequency of occurrence of the -308GA/-376GG genotype combination in the subgroup in which the pregnancy ended $<37$ weeks ( 32.61 vs. $19.26 \%$, OR $=2.03$, $p=0.05)$ and in the subgroup of women with $\geq 3$ points. UAS (41.18 vs. $19.26 \%, \mathrm{OR}=2.93, p=0.01$ ). In the subgroup of women with $\geq 3$ points UAS also noted a higher frequency of the combination of -238GG / -308GA genotypes (41.18 vs. $18.52, \mathrm{OR}=3.08, \mathrm{p}=0.01$ ). These observations indicate possible common interaction of genotypes and alleles of several TNF- $a$ gene polymorphisms at the severity of IUGR-related complications.

In the work of Laddha et al. (2012) five promoter polymorphisms of the TNF- $a$ gene were studied [-238G $>A$ (rs361525), -308G > A (rs1800629), -857C > T (rs1799724), $-863 C>A(r s 1800630)$ and $-1031 T>C(r s 1799964)]$ in a group of 977 Indian patients with vitiligo and 990 healthy controls. Analysis of linkage disequilibrium showed a weak or moderate LD relationship between these five TNF- $a$ variants. The two polymorphisms studied also in the presented dissertation $(-238 G>A$ and $-308 G>A$ ) in the article of Indian researchers occurred in moderate $L D\left(D^{\prime}=0.485\right)[16]$. Palmirotta et al. (2010) investigated the relationship between serum TNF-a serum concentration and TNF-a gene promotor polymorphisms $(-376 G>A,-308 G>A$ and $-238 G>A)$ in the group of 200 Italian Caucasian women. The study group consisted of 100 patients (mean age $37 \pm 5$ years, range 25-47) who had unexplained recurrent spontaneous abortions ( $n=31)$ or idiopathic infertility $(n=69)$. 100 healthy fertile women from the same geographical area (mean age $38 \pm 5$ years, range $23-48$ ) were qualified to the control group. In this work, the analysis of the coupling disequilibrium determined by the D'coefficient did not show any coupling disequilibrium between all three promoter variants. Genetic analysis showed a more frequent occurrence of the $-238 \mathrm{G}$ allele $(p=0.028)$ and haplotype 3-loci $(-376 G /-308 A /-238 G)$ in the control group compared to women with pregnancy failure $(p=0.020)$. In this study, serum TNF-a protein was higher in the study group (1.5 [0.1-11.4] vs. $0.1[0.1-3.8]$ $\mathrm{pg} / \mathrm{mL}, p=0.001)$, and multivariate regression analysis indicated that the previously mentioned haplotype $(-376 G / A$, -308G / $A$ and -238G / $A$ ) is an independent factor associated with a lower level of TNF-a protein $(p=0.021)$ and the occurrence of abortions ( $p=0.023$ ). The authors suggest the association of TNF-a polymorphisms with recurrent miscarriages, particularly the $-238 G G$ variant and haplotype $(-376 G /-308 A /-238 G)$ as protective factors for recurrent pregnancy loss [17].

In the above work, exactly the same three promoter polymorphisms were analyzed, in a numerically similar group of Polish, Caucasian patients and similarly, the analysis of linkage disequilibrium did not show LD between the variants discussed. Haplotype (-376G / -308A / -238G) described in Palmirott et al. as a protective factor for the occurrence of pregnancy failure in the presented study was more frequent in the IUGR group compared to the control group $(0.157 \%$ 
vs. $0.119 \%)$, but no statistically significant difference was observed $(p=0.21)[16,17]$.

\section{CONCLUSIONS}

1. More frequent occurrence of TNF-a mutated allele $-308 A$ in a subgroup of women whose pregnancy ended $<37$ weeks suggests the possible significance of this variant in the etiology of IUGR.

2. The statistically significant advantage of the TNF-a mutated -308 A allele in the group of women with a score $\geq 3$ UAS may indicate the significance of this variant in IUGR prediction.

3. The presence of the TNF-a heterozygous -308GA genotype is associated with a nearly 3 -fold increase in the risk of three or four abnormalities in the point scale of uterine artery flow (UAS) and may be used in the prediction of IUGR.

\section{REFERENCES}

1. Resnik R. Intrauterine growth restriction. Obstet Gynecol. 2002; 99(3): 490-496, doi: 10.1097/00006250-200203000-00020, indexed in Pubmed: 11864679

2. Campbell LR, Pang Yi, Ojeda NB, et al. Intracerebral lipopolysaccharide induces neuroinflammatory change and augmented brain injury in growth-restricted neonatal rats. Pediatr Res. 2012; 71(6): 645-652, doi: 10.1038/pr.2012.26, indexed in Pubmed: 22337231.

3. Mandruzzato G, Antsaklis A, Botet F, et al. WAPM. Intrauterine restriction (IUGR). J Perinat Med. 2008; 36(4): 277-281, doi: 10.1515/JPM.2008.050, indexed in Pubmed: 18598115.

4. Ropacka-Lesiak M, Breborowicz G. [Management of pregnancy complicated by intrauterine fetal growth restriction]. Ginekol Pol. 2012; 83(5): 373-376, indexed in Pubmed: 22708336.

5. Hattersley AT, Tooke JE. The fetal insulin hypothesis: an alternative explanation of the association of low birthweight with diabetes and vascular disease. Lancet. 1999; 353(9166): 1789-1792, doi: 10.1016/S01406736(98)07546-1, indexed in Pubmed: 10348008.
6. Hunt JS, Chen HL, Miller L. Tumor necrosis factors: pivotal components of pregnancy? Biol Reprod. 1996; 54(3): 554-562, doi: 10.1095/biolreprod54.3.554, indexed in Pubmed: 8835376.

7. Haider S, Knöfler M. Human tumour necrosis factor: physiological and pathological roles in placenta and endometrium. Placenta. 2009; 30(2): 111-123, doi: 10.1016/j.placenta.2008.10.012, indexed in Pubmed: 19027157.

8. Giannubilo SR, Tranquilli AL. Anticoagulant therapy during pregnancy for maternal and fetal acquired and inherited thrombophilia. Curr Med Chem. 2012; 19(27): 4562-4571, doi: 10.2174/092986712803306466, indexed in Pubmed: 22876895.

9. Kilani RT, Mackova M, Davidge ST, et al. Endogenous tumor necrosis factor alpha mediates enhanced apoptosis of cultured villous trophoblasts from intrauterine growth-restricted placentae. Reproduction. 2007; 133(1): 257-264, doi: 10.1530/REP-06-0080, indexed in Pubmed: 17244751.

10. Nedwin GE, Naylor SL, Sakaguchi AY, et al. Human lymphotoxin and tumor necrosis factor genes: structure, homology and chromosomal localization. Nucleic Acids Res. 1985; 13(17): 6361-6373, doi: 10.1093/nar/13.17.6361, indexed in Pubmed: 2995927.

11. Takashiba S, Shapira L, Amar S, et al. Cloning and characterization of human TNF alpha promoter region. Gene. 1993; 131(2): 307-308, doi: 10.1016/0378-1119(93)90314-s, indexed in Pubmed: 8406029.

12. Amu S, Hahn-Zoric M, Malik A, et al. Cytokines in the placenta of Pakistani newborns with and without intrauterine growth retardation. Pediatr Res. 2006; 59(2): 254-258, doi: 10.1203/01.pdr.0000196332.37565.7d, indexed in Pubmed: 16439588.

13. Molvarec A, Jermendy A, Nagy B, et al. Association between tumor necrosis factor (TNF)-alpha G-308A gene polymorphism and preeclampsia complicated by severe fetal growth restriction. Clin Chim Acta. 2008; 392(1-2): 52-57, doi: 10.1016/j.cca.2008.03.009, indexed in Pubmed: 18396154.

14. Kaiser T, Grehan M, Brennecke SP, et al. Association of the TNF2 allele with eclampsia. Gynecol Obstet Invest. 2004; 57(4): 204-209, doi: 10.1159/000076689, indexed in Pubmed: 14963369.

15. Saarela T, Hiltunen $M$, Helisalmi $S$, et al. Tumour necrosis factor-alpha gene haplotype is associated with pre-eclampsia. Mol Hum Reprod. 2005; 11 (6): 437-440, doi: 10.1093/molehr/gah182, indexed in Pubmed: 15901845

16. Laddha NC, Dwivedi M, Begum R. Increased Tumor Necrosis Factor (TNF)-a and its promoter polymorphisms correlate with disease progression and higher susceptibility towards vitiligo. PLoS One. 2012; 7(12): e52298, doi: 10.1371/journal.pone.0052298, indexed in Pubmed: 23284977.

17. Palmirotta R, La Farina F, Ferroni $\mathrm{P}$, et al. TNFA gene promoter polymorphisms and susceptibility to recurrent pregnancy loss in Italian women. Reprod Sci. 2010; 17(7): 659-666, doi: 10.1177/1933719110366603, indexed in Pubmed: 20388617. 